\title{
Psykisk helse i skolen
}

Ved Tonje H oug

En god psykisk helse er viktig for å mestre livet. De fleste norske barn er friske og har en god psykisk helse, men psykiske plager og lidelser er den største kilden til helseproblemer blant barn og ungdom. Gjennom satsingen "Psykisk helse i skolen" skal alle landets skoler inviteres til et samarbeid for bedre å ivareta barn og unges psykiske helse.

Psykisk helse i skolen er et tilbud om ulike undervisningsmoduler for lærere og elever i ungdomsskole og videregående skole. $M$ ålet med programmene er tredelt. Elevene skal få kunnskap om hvordan de kan ivareta egen psykisk helse. De skal gis kunnskap om hvordan de kan støtte hverandre når noen sliter. Sist, men ikke minst, skal de få kunnskap om hvor en kan henvende seg for å få hjelp. Lærerne på sin side skal få kunnskap om psykiske plager og lidelser hos ungdom og et verktøy for å undervise ungdom om psykisk helse og uhelse.

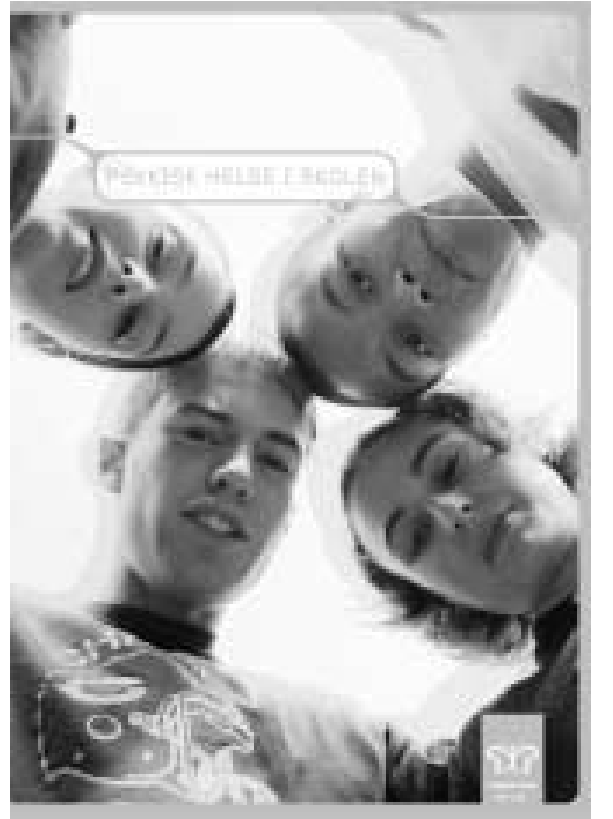

\section{Psykisk helse}

Programmene i Psykisk helse i skolen bygger, på lik linje med 0 pptrappingsplanen for psykisk helse, på en forståelse av at den psykiske helsen påvirkes av både individuelle, mellommenneskelige og samfunn smessige faktorer - og samspillet mellom disse. Psykisk helse forstås som et kontinuum, med svært god helse i den ene enden og dårlig psykisk helse, f.eks. alvorlige psykiske lidelser i den andre enden.

M ed psykiske plager siktes det ofte til tilstander som kan ha følger for trivsel og funksjon i hverdagen, som f.eks. hode- pine, angst og uro. Psykiske lidel ser kan sorteres etter diagnostiske systemer som ICD-10 (International Classification of Diseases) eller DSM -IV (Diagnostic and Statistical M anual for the M ental Disorder).

Barn og unges psykiske hel se angår oss alle. I regjeringens strategiplan for barn og unges psykiske helse (2003) lanseres hundre tiltak for å styrke deres psykiske helse. Psykisk helse i skolen er blant dem. I strategiplanen pekes det på utfordringen i å hindre at barn og unge blir isolert, at de blir mobbet og trakassert. Ensomhet omsorgssvikt og mishandling kan føre til større problemer på skolen, spiseforstyrrelser, rusmisbruk og kriminalitet. For noen barn blir problemene så store at de fører til psykisk sykdom. U ndersøkelser viser at 15-30 prosent av barn og ungdom har mindre eller større psykiske plager eller lidelser. M ellom fire og sju prosent er behandlingstrengende. (R egjeringens strategiplan for barn og unges psykiske helse ... sammen om psykisk helse (2003). En stor del av dem som sliter oppsøker ikke hjelpeapparatet (H eltef, 2004).

A lle elever i grunnskolen og i videregående utdanning har, i føl ge kapittel 9 a i opplæringsloven, rett til et godt fysisk og psykososialt miljø som fremmer helse, trivsel og læring. $\AA$ arbeide fram et godt skolemiljø, der elevene føler tilhørighet og har gode relasjoner, kan være ett bidrag til å redusere ensomhet, isolasjon og mobbing.

\section{Om åpenhet}

U ndersøkelser viser også at ungdom vet lite om psykiske lidelser ( 0 pinion, 2002). Dette bidrar til mange fordommer i denne aldersgruppa. $\varnothing$ kt kunnskap om psykiske problemer og endring av holdninger for å skape større åpenhet og aksept kan bidra til at de som har det vondt, får det bedre.

$M$ ange søker faktakunnskap, og ikke minst ungdom er opptatt av fakta om psykiske lidelser (O pinion, 2002). M anglende åpenhet om temaet bidrar til at både unge og voksne opplever at det er vanskeligå snakke om psykiske
U ndervisningsprogrammene som hører inn under paraplyen Psykisk helse i skolen er koordinert av Sosialog hel sedirektoratet i samarbeid med U tdanningsdirektoratet, Barne- og familiedepartementet, $M$ ental $\mathrm{H}$ else N orge, Rådet for psykisk helse, Stiftelsen Psykiatrisk Opplysning og Voksne for barn. Programmene er en del av informasjonssatsingen i 0 pptrappingsplanen for psykisk helse og regjeringens strategiplan for barn og unge, "... sammen om psykisk helse" (2003)

U ndervisningsprogrammene er benyttet i mange skoler og er evaluert med gode resultater. Det er opprettet et eget sekretariat for satsingen.

Programmene skal først implementeres i tre pilotfylker: Telemark, O ppland og Buskerud. M ålet er at alle skoler skal få tilbud om undervisningsprogrammene innen 2008.

\section{Psykisk helse i skolen} TIf: 51892950

utfordringer og problemer. Informasjon om tematikken kan føre til gjenkjennelse.

U ndervisningsprogrammene bidrar til at elevene utvikler et eget språk for å kunne snakke om og bli tryggere på psykisk helse. A Iminneliggjøringen av psykisk helse kan blant annet bidra til at den enkelte opplever økt ansvar for egen helse, bryr seg mer om egen atferd overfor andre og at forventningen til hjelpeapparatet avpasses med hva som kan og bør tilbys

\section{Del av informasjonssatsing}

Tiltakene i Psykisk helse i skolen er utviklet som en del av Sosial- og helsedirektoratets informasj onssatsing "N oe å snakke om... ?". Satsingen inngår som en del av O pptrappingsplan for psykisk helse (St. prp.nr 63), som er en tiltaksplan for alle 


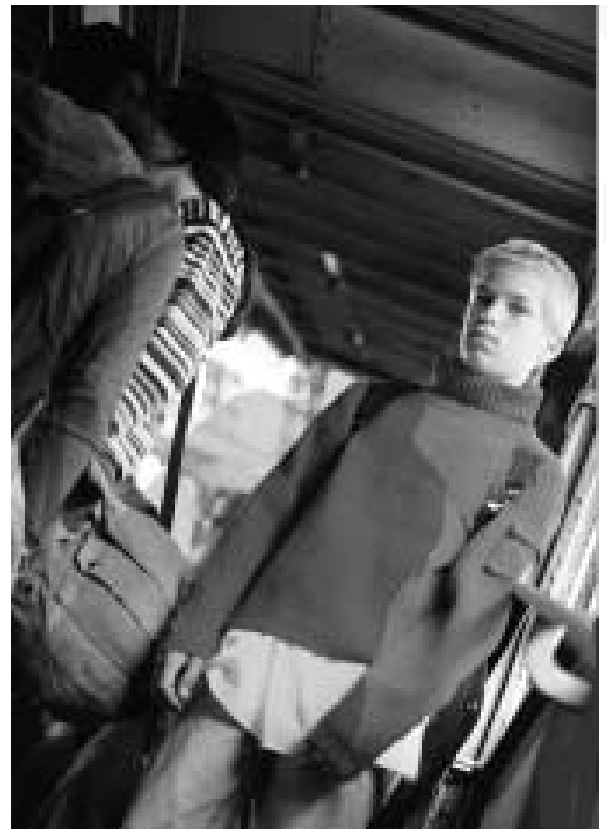

med psykiske problemer og lidelser. I informasjonssatsingen er det formulert et overordnet mål om å bidra til økt åpenhet om psykisk helse, redusere myter og tabuer og gi kunnskap om psykiske problemer og lidelser til befolkningen generelt.

\section{Fortløpende evaluering}

I tråd med de bærende elementer i Folkhelsemeldingen vektl egger informasjonssatsingen helsefremmende og forebyggende tiltak. H er ligger det også en normaliseringsforståel se til grunn. A lle har en psykisk helse, og de fleste av oss kan bli psykisk syke en eller annen gang i løpet av livet. En rekke av tiltakene rettes mot det som kan bidra til god psykisk helse, for eksempel sosiale nettverk. Det fokuseres også på at faser i livet kan oppleves som vanskel ig, f.eks. ungdomstida, men at det meste er utfordringer som alle møter.

Informasjonssatsingen har som mål å bidra til at den enkelte făr kunnskap som setter en i stand til å ivareta egen og andres helse. Det informeres også om ulike psykiske lidelser. Informasjon om helse, i et forsøk på å forebygge sykdom, har i enkelte tilfeller vist seg å gi motsatt effekt. Kampanjer mot rusbruk har bl.a. ført til økt rusmisbruk (H olth, 2003). Informasjonssatsingen er opptatt av å unngå å sykeliggjøre befolkningen, samtidig som det er et mål å informere om vanlige psykiske lidelser som for eksempel angst og depresjon. For å unngå sykeliggjøring utformes og testes tiltakene på målgruppene, og de evalueres fortløpende.

\section{Keferanser}

Feedback Research . (2000). R apport om kunnskaps- og holdningsundersøkelse, Feedback Research

H el sedepartementet. (2003). ...sammen om psykisk helse. Regjeringens strategiplan for barn og unges psykiske hel se.

HELT EF. (2004). H elseprofil for barn og ungdom i A kershus - ungdomsrapporten. Rapport nr 2/ 2004. N asjonalt kunnskapssenter for helsetjen esten.

$\mathrm{H}$ olth, P. (2003). Kan forebygging skade? R us og avhengighet 2: 20-22

0 pinion. (2002). U ngdoms holdninger til psykisk helse.

O pplæringsloven. Lov om grunnskolen og den vidaregåande opplæringa. O slo: U tdannings- og forskningsdepartementet, 1998. Sist endret 2004.

Sosial- og helsedepartementet (2000). Faktarapport om årsaker til psykiske plager og lidelser. A vgitt av ekspertgruppe til Sosial- og hel sedepartementet, januar 2000.

St. meld. nr. 16 (2002-2003). R esept for et sunnere $\mathrm{N}$ orge. Folkehelsepolitikken

St.prp. nr. 63 (1997-98) O pptrappingsplan for psykiske helse. O slo: Sosial- og helsedepartementet, 1998.

Sverdrup, S. \& Bratt, C. (2003). Kunnskap og åpenhet om psykisk helse og psykiske lidelser. NIBR 2003:5

\section{Presentasjon av programmene}

\section{Elever i ungdomsskolen: Alle har en psykisk helse}

U ndervisningspakken A lle har en psykisk helse er utviklet for å gi ungdom mer kunnskap om psykisk helse. U ndervisningstilbudet er til passet lærerplanens generelle del og er lagt opp som prosjektarbeid av opp til tre dagers varighet. I oppgavene er det stor grad av elevstyring, men læreren gis et verktøy for å strukturere val gene og sette dem inn $i$ en større helhet.

\section{Tema tilpasset alder} og situasjon

Temaer og struktur varierer i forhold til elevenes alder, skolesituasjon og forhåndskunnskap. I 8. klasse er det f.eks. stram struktur og flere mindre oppgaver som sikrer

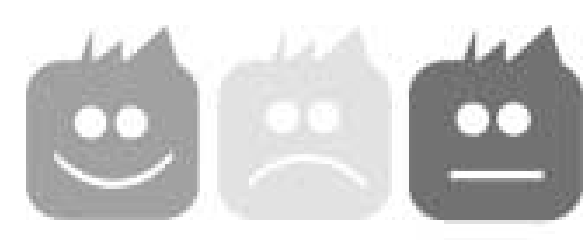

ALLE HAR EN PSYKISK MELSE at alle făr en helhetlig innføring i psykisk helse, mens elevene i 9. og 10. klasse gis stor frihet. Læreren skal være veileder, ikke terapeut. Det er et mål at el evene utvikler eget språk for å kunne snakke om og bli tryggere på egen og andres psykiske helse. De unge får også kunnskap om hvor de kan få hjelp năr livet blir vanskelig å mestre. Undervisningspakken inneholder en egen veiledningsmodul for læreren. Her vil prosjektarbeid og temaet psykisk helse utdypes. 
Elever i videregåen de skole: venn1.no

venn1. no er rettet mot al dersgruppen 16 - 20 år, og handler om hvordan ungdom kan ivareta egen psykisk helse og ha vennskap med andre som har det vanskelig. Kurset har ikke som ambisjon å fjerne ungdommenes psykiske problemer, men bidra til å fokusere på hvor viktig det er med vennskap og aksept fra venner.

venn1. no består av tre undervisningspakker som bygger på hverandre:

Basispakken:

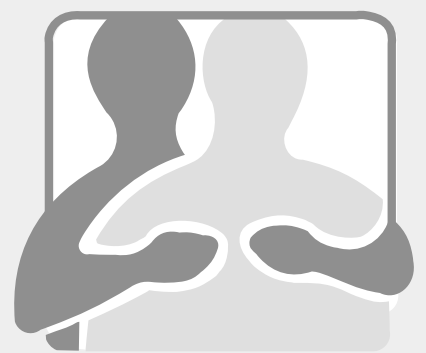

MENTAL HELSE
Skoler som har begrenset tid til rådighet kan velge basispakken med en tidsramme på tre sammenhen gende skoletimer.

A til $\AA$-pakken er for skoler som kan involvere flere lærere og foreldrene. $\AA$ til $\AA$-pakken bygger på basispakken, men inkluderer timer i fagene, norsk, samfunnslære, kroppsøving og engelsk. Tidsrammen er tre sammenhengen de skoletimer, diverse fagtimer og foreldremøte. Full skoleuke bygger på basispakken. $\mathrm{H}$ er kan skolene la flere klasser jobbe prosjektrelatert samt involvere flest mulig lærere og foreldre. Full skoleuke varer fra mandag til fredag pluss et foreldremøte. venn 1. no supplerer og kan gjerne kombineres med val gfaget

Step - ungdom møter ungdom.

Elever i videregående skole:

\section{STEP - ungdom møter ungdom}

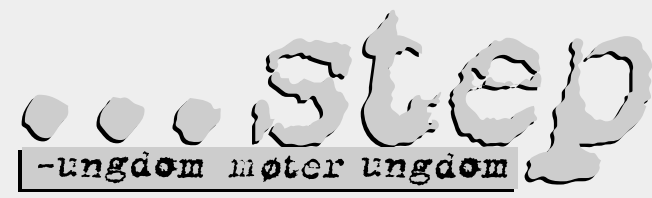

STEP er et valgfag der elevene arbeider aktivt med det psykososiale miljøet på sin egen skole. Programmet er mestringsorientert, og hovedmål et er å øke unges kunnskaper, innsikt og mulighet til å mestre sin egen livssituasjon og utvikling. Dette er i tråd med opplæringslovens krav om at ungdommene selv skal trekkes inn i arbeidet med skolens psykososiale miljø.

STEP - ungdom møter ungdom består av:

Samtaletjen este der ungdom bistår yngre og jevnaldrende i spørsmål som berører hverdagslivet. D e får opplæring i kommunikasjon og samtal eteknikk for å bli mer bevisste på hvordan de kan gi støtte til andre ungdommer.

U ngdommene får opplæring i hvordan de kan drive grupper for yngre ungdommer etter et godt utprøvd program. I tillegg kan ungdommene utforme egne tiltak ut fra behov som viser seg i skolen eller i deres miljø. Eksempler på dette er trivselsundersøkelser, arrangere dager hvor man fokuserer på det psykososiale miljøet, etablere fadderordning og liknende.

Elevene får oversikt over hjel peinstanser i lokalsamfunnet. A ndre temaer for opplæringen er rusmisbruk, spiseforstyrrelser, relasjoner og vennskap, mestring, seksual itet, identitet, selvbilde og presentasjonsteknikk.

U ngdom som rekrutteres for å bli samtal epartnere, får opplæring og veiledning av rådgiver, helsesøster eller andre som kan være et støttenettverk (f. eks. pp-tjenesten).

Step - ungdom møter ungdom supplerer og kan gjerne kombineres med undervisningspakken venn 1. no.
Lærerkurs:

\section{Hva er det med Monica?}

$\mathrm{H}$ va er det med M onica? er et kurs for lærere og andre yrkesgrupper som arbeider med ungdom. Kurset skal hjelpe lærere til større sikkerhet og mulighet til handling i forhold til elever som sliter med angst, depresjon, spiseforstyrrelser og andre former for psykiske plager og lidelser. H er blir det også presentert gode samarbeidsmodeller for skole og hjelpeapparat.

Kunnskap om psykisk helse virker forebyggende. G jennom sin kontakt med elevene kan Iæreren tidlig oppdage symptomer på at elever har det vanskelig. Kurset skal være en arena for informasjons- og erfaringsutveksling lærere imellom og mellom fagfolk og lærere.

Kurset skal bidra til å:

- øke kunnskap og forståelse blant Iærere om psykiske plager hos ungdom

- styrke lærerrollen generelt og kontaktlærer/klassestyrer spesielt i møte med el ever som sliter psykisk

- gi et verktøy til å implementere kunnskap om psykisk helse og psykiske plager og lidelser $\mathrm{i}$ undervisningen.
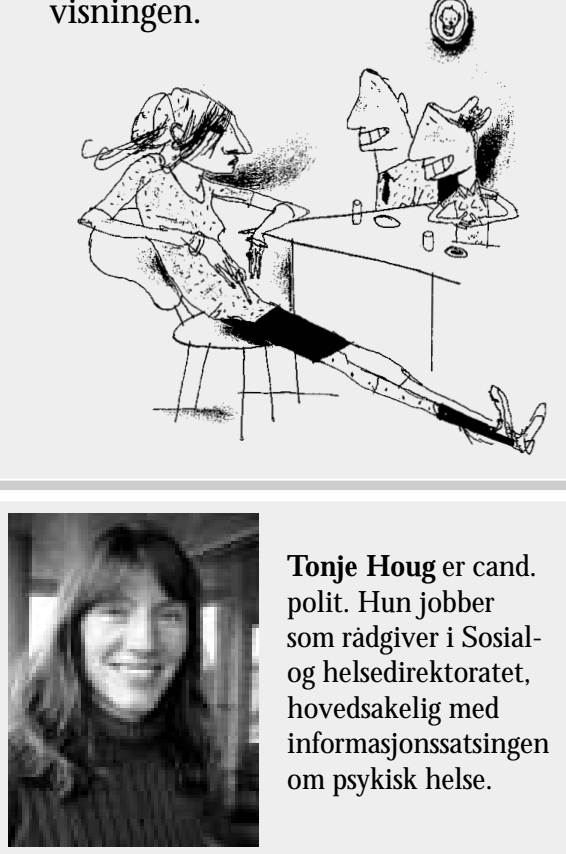

Tonje H oug er cand. polit. H un jobber som rådgiver i Sosialog hel sedirektoratet, hovedsakelig med informasjonssatsingen om psykisk helse. 